\title{
Bancroftian filariasis in Belém, Pará State. Possibilities for Eradication by Introducing Modern Methods of Control for Culex quinquefasciatus
}

\author{
A Filariose Bancroftiana em Belém, Pará. Possibilidades Atuais de \\ Erradicação Mediante a Integração à Campanha de Novos Métodos de \\ Controle da População de Culex quinquefasciatus
}

\begin{abstract}
Habib Fraiha Neto ${ }^{1}$
FRAIHA-NETO, H. Bancroftian filariasis in Belém, Pará State. Possibilities for Eradication by Introducing Modern Methods of Control for Culex quinquefasciatus. Cad. Saúde Públ., Rio de Janeiro, 9 (4): 458-465, Oct/Dec, 1993.

For the past four decades, Belém has been considered to be the largest focus of Bancroftian filariasis in the Amazon region and one of the most important ones in Brazil. In 1952,

practically one-fifth of the population was infected and it was estimated that there were 2,500 cases of Bancroftian elephantiasis. The major factor considered to be responsible for this situation was the high density of the main vector species: it was calculated that in April 1943 there was a mean of 67 infected mosquitoes per house. A control campaign was initiated in 1952, involving treatment of patients with diethylcarbamazine, as well as control of the vector. In 1956, vector control was discontinued because of a lack of efficient insecticides and financial limitations. Even so, the campaign was very successful and the incidence was reduced from $19.9 \%$ to $0.03 \%$. Total eradication could be achieved if new methods of vector control were introduced, such as the use of Reiter's expanded polystyrene balls in cesspits and pit latrines, biological control using pathogenic bacteria, and improvement of basic sanitation.
\end{abstract}

Key words: Bancroftian filariasis; Culex quinquefasciatus; Vector Control; Amazonia

\section{INTRODUCTION}

In the middle of this century, Bancroftian filariasis constituted a serious problem in Belém, the capital of Pará State. Filariasis of Asiatic origin, imported from Africa to the New World through the slave trade, had adapted perfectly to the environment in Belém, thanks to the presence of the mosquito Culex quinquefasciatus Say, 1823 (Diptera, Culicidae).

This species, long known in Brazil by the name Culex pipiens fatigans (a name which has now been substituted by the other, owing

${ }^{1}$ Instituto Evandro Chagas, Fundação Nacional de Saúde. Avenida Almirante Barroso, 492, Belém, PA, 66090-000, Brasil. to chronological priority), was at that time known to be not only the best vector of Bancroftian filariasis, but also the principal agent by which the disease had been transmitted in the Americas (Rachou, 1956; 1957). Although other species of mosquito have been found to be naturally infected in Brazil (Anopheles darlingi, A. aquasalis, A. bellator, and possibly Aedes scapularis with the first two found carrying infective forms of the parasite), these dipterans are considered to be secondary vectors that are of epidemiological significance only when high levels of microfilaremia have already been established via the principal vector (Rachou, 1957).

In addition to the high vectorial capacity of C. quinquefasciatus, which results from a number of highly expressed behavioural 
characteristics (strong domiciliarity and anthropophilia, extreme susceptibility to infection by Wuchereria, life-span well in excess of that required for the development of infective parasite forms) (Rachou, 1956), a further factor in Belém was the extraordinarily high density of the mosquito population, enough to constitute a veritable nightmare for the inhabitants of the city. Emilio Goeldi (1905), in his memorable work on the mosquitoes of Pará, offered various descriptions of this situation: "Horrific nocturnal scourge here in Belém, affecting human habitations in various parts of the city"; "intolerable enemy of our nightly slumber"; "the prevalence of this insolent pest is simply staggering: in the area of Nazareth it attacks houses in the first hours of the night, flying in clouds of myriads, invading by way of windows and doors, dashing against our faces like a permanent shower of coarse flour"; "the music or buzzing emmitted simultaneously by thousands of mosquitoes, in a dark room, is enough to make our hair stand on end!"; "we have thousands of them in our bedrooms, and if, as a rule, we kill hundreds - I remember one night when, in one room alone, no less than 143 of these mosquitoes were killed in a short space of time - there are always several hundred still left to turn the night into a time of veritable torture" (Goeldi, 1905).

Almost 40 years later, when researchers from the Evandro Chagas Institute were carrying out the first studies on the incidence and transmission of Wuchereria bancrofti in Belém, they noted the continuing "extreme abundance" of this species of mosquito throughout the city. They mentioned that routine catches carried out in the bedrooms of 1,641 buildings by the staff of Belém's mosquito control service in the first 7 months of 1943 yielded a total of 548,262 specimens; in other words, an average of 334 mosquitoes per house. More than $99 \%$ of them were "Culex fatigans". The research team also noted that, in the months of April and May, this average went up to 585 and 509 mosquitoes per house, respectively (Causey et al., 1945) - giving what was later considered to be one of the highest domiciliary densities of this species in Brazil (Rachou, 1956). Worse still, the natural infection rate of the mosquito with Wuchereria was $11.6 \%$; in other words, during that particular April, each house contained an average of 67 infected females! (Causey et al., 1945).

More or less at the same time, Amilcar Vianna Martins, author of the first inquiry of Bancroftian filariasis in Belém (Deane \& Damasceno, 1952), dissected 81 Culex specimens and found 19 of them infected, giving a rate of natural infection of $23.45 \%$ (apud Costa, 1954).

Another study, carried out subsequently by Deane (1951) in 20 houses in two parts of Belém (Marco and Pedreira), between June 1948 and June 1949, gave an average hourly count of 109.2 Culex specimens, equivalent to more than $99.9 \%$ of all types of mosquito caught. The highest average hourly count in a single month - 258.6 - was registered in March, at the height of the rainy season. The lowest average hourly count, recorded in December, was still relatively high: 58.6. Thus, in these two study areas, the species proved to be prevalent throughout the year, suggesting that any control program would require more than one application per year of the available insecticides.

As for the state of the filariasis endemic itself, the results of the first investigation carried out in Belém had clearly characterized the extent of the health problem: out of a total of 472 soldiers interned for innumerable different reasons in Belém's military hospital, $8.05 \%$ were found to be carrying microfilariae (Martins, 1945 apud Costa, 1954); of 5,000 city inhabitants examined between November 1942 and December 1943, $12 \%$ were found to be carriers of microfilaremia and/or elephantiasis (Causey et al., 1945); and of 8,529 inhabitants examined in $1921,9.8 \%$ were positive (Deane \& Damasceno, 1952).

This slight decline appeared to have resulted from domestic insecticide spraying during antimalarial campaigns carried out from 1946 onwards in many parts of the city.

Nonetheless, some areas, such as Guamá and Canudos together, had positive infection rates as high as $14.5 \%$ (Deane \& Damasceno, 
1952). Nothing, or almost nothing, had been done to prevent the endemic from spreading locally (Scaff \& Gueiros, 1969).

In the light of the results mentioned above, Belém became the obvious candidate for Brazil's first attempt at controlling Bancroftian filariasis. Under the auspices of the Ministry of Health, a control campaign was carried out by the then National Malaria Service (Deane \& Damasceno, 1952; Scaff \& Gueiros, 1967).

Work began in 1952, with an attack on the adult forms of the vector, using the residual insecticide BHC (benzene hexachloride), and with treatment of microfilariae carriers with diethylcarbamazine (Scaff \& Gueiros, 1967; Franco \& Silva Lima, 1967).

A study carried out in the same year by The National Malaria Service gave results that were even more shocking than any previous data: $19.9 \%$ - i.e., practically one in five of the city's inhabitants were microfilaremic, giving an estimated total of 50,000 infected individuals, with 2,500 of these already physically deformed as a result of elefanthiasis (Rachou, 1957). At that time it was common to see sufferers of the disease in the streets, with their deformities poorly disguised.

The following year, once it had been established that BHC worked less efficiently when applied in such a way as to make use of its residual effects, a new strategy was adopted, based on controlling the aquatic forms of the vector. However, this approach was expensive, and it was therefore not possible to carry out applications at weekly intervals, given the mosquito's development time from egg to adult. Thus, part of the city was treated once a fortnight, and the rest once a month (Scaff \& Gueiros, 1967).

In 1955, with the arrival of dieldrin, there was renewed hope that attacks against adult mosquitoes might now be feasible. However, within a short time, this product too was found to be ineffective against Culex.

In 1956, all attempts at attacking the vector in Belém were abandoned: as far as the adult forms of the insect were concerned, no effective insecticide had yet been found; and, as for the aquatic forms, the cost of continuous weekly applications of antilarval compounds was prohibitive. Thus, attention came to be focused on humans as the source of infection. The method involved: collection at night of blood samples from the bulk of the population, for the purposes of detecting microfilariae; free treatment of all cases found to be positive, with diethylcarbamazine; and health education (Scaff \& Gueiros, 1967).

The results of this campaign can be seen in the following table: (Table 1)

There was thus an appreciable, progressive and systematic fall in the rates of microfilaremia in Belém, almost entirely because of treatment administered to the sources of infection. The campaign was carried out in a serious and competent manner, first by the National Malaria Service, then by Departamento Nacional de Endemias Rurais (DNERu), and finally by Superintendência de Campanhas de Saúde Pública (Sucam).

Other towns in the state of Pará that were once affected, such as Soure, Cametá and Vigia (Scaff \& Gueiros, 1967), are today considered to be extinct foci. The problem is thus now confined to the Greater Belém area, and even there appears to be on the road to extinction, thanks mainly to continuous coverage of priority areas (Sucam, 1989).

Now that we are on the verge of seeing this disease eradicated, it would be worth taking heed of the final recommendations offered by the National Workshop (1989) in Recife, namely that efforts should also be made to control the vector, through environmental management designed to eliminate breeding sites. This approach would be all the more feasible given recent alternative proposals for control (that, as well as costing little, also promise to be highly effective), and notable scientific advances in terms of biological control of aquatic forms of the insect, using entomopathogenic organisms.

\section{NEW PROPOSALS FOR VECTOR CONTROL}

Raced with the ever growing resistance of medically and economically significant insects to chemical insecticides, together with the 
TABLE 1. Results of Blood Tests for the Detection of W. bancrofti Microfilariae Carried Out in the City of Belém, 1951-1990

\begin{tabular}{rrrrr}
\hline \hline & \multicolumn{3}{c}{ People Examined } & \multicolumn{2}{c}{ People with Microfilariae } \\
\cline { 2 - 5 } Year & Number & \% Total Pop. & Number & $\%$ \\
\hline 1951 & 8,588 & - & 845 & 9.8 \\
1952 & 31,625 & - & 6,306 & 19.9 \\
1953 & 49,417 & - & 6,721 & 13.6 \\
1954 & 43,824 & - & 4,148 & 9.5 \\
1955 & 45,501 & - & 5,595 & 12.3 \\
1956 & 67,021 & - & 5,953 & 8.9 \\
1957 & 163,579 & - & 13,826 & 8.5 \\
1958 & 215,579 & - & 14,231 & 6.6 \\
1959 & 238,943 & - & 13,012 & 5.4 \\
1960 & 274,763 & - & 10,713 & 3.9 \\
1961 & 227,016 & - & 9,737 & 4.3 \\
1962 & 242,183 & - & 8,110 & 3.3 \\
1963 & 308,835 & - & 9,110 & 2.9 \\
1964 & 278,678 & - & 6,828 & 2.5 \\
1965 & 264,850 & 75.1 & 4,566 & 1.7 \\
1966 & 243,597 & 62.2 & 4,379 & 1.8 \\
1967 & 222,649 & 52.1 & 4,353 & 1.9 \\
1968 & 195,675 & 38.1 & 2,471 & 1.3 \\
1969 & 192,765 & 33.5 & 2,596 & 1.2 \\
1970 & 339,882 & 60.4 & 3,862 & 1.1 \\
1971 & $* 291,508$ & 51.5 & $* 2,540$ & 0.9 \\
1972 & 316,835 & 55.7 & 2,753 & 0.9 \\
1973 & 230,809 & 36.0 & 2,283 & 0.9 \\
1974 & 216,412 & 31.3 & 2,027 & 0.9 \\
1975 & 186,953 & 25.8 & 2,338 & 1.2 \\
1976 & 345,853 & 44.6 & 2,668 & 0.8 \\
1977 & 670,174 & 86.6 & 3,657 & 0.5 \\
1978 & 547,781 & 68.7 & 2,184 & 0.5 \\
1979 & 538,361 & 55.3 & 1,733 & 0.3 \\
1980 & 553,782 & 56.6 & 1,723 & 0.3 \\
1981 & 423,226 & 42.5 & 1,114 & 0.3 \\
1982 & 376,425 & 46.0 & 1,003 & 0.3 \\
1983 & 347,605 & 38.8 & 705 & 0.2 \\
1984 & 285,031 & 31.3 & 322 & 0.1 \\
1985 & 326,698 & 35.7 & 324 & 0.09 \\
1986 & 310,458 & 31.7 & 216 & 0.06 \\
1987 & 304,704 & 31.5 & 117 & 0.04 \\
1988 & 279,152 & 27.3 & 90 & 0.03 \\
1989 & 232,200 & 18.9 & 79 & 0.03 \\
1990 & 225,674 & 18.4 & 71 & 0.03 \\
\hline \hline & & & &
\end{tabular}

Source: National Health Foundation (Regional Directorate/Pará).

*Data different to that supplied by SUCAM (environmental disease control agency) in 1977: 345,663 and 3,117, respectively. The rate of infection, however, is the same: $0.9 \%$ (Fraiha-Neto, 1977). 
public pressure exerted by ecologists in defense of the environment, researchers in recent decades have increasingly focused their efforts on trying to find alternative solutions. As far as $C$. quinquefasciatus is concerned, a variety of interesting control methods have been proposed, the most significant of which are:

\section{Biological Control Using Entomopathogenic Bacteria}

Microorganisms from the genus Bacillus, in particular certain strains of $B$. thuringiensis and $B$. sphaericus, produce toxins that have a potent effect on larvae of $C$. quinquefasciatus. Its entomopathogenic potential was sufficiently proved in different regions of the world, such as in Polinesia, Indonesia, West Africa, Egypt, India and Sri Lanka (Wickremesinghe \& Mendis, 1981).

Larvicides based on serotype $\mathrm{H}-14$ of $B$. thuringiensis var. israelensis, for example, have proved to be highly effective against mosquito and simulid (black fly) larvae of many countries (Canada, Cuba, Czechoslovakia, Egypt, Germany, France, Israel, Ivory Coast, Nigeria, Switzerland, Soviet Union, United States and Yugoslavia) (WHO, 1979). The capacity of this bacterium to kill larvae results from various properties displayed by its crystalline deltatoxin: rapid toxicity; wide spectrum of action on insect vectors, even at low concentrations; nontoxicity for humans and for other nontarget animals, including the larvae's natural predators (Wickremesinghe \& Mendis, 1981). This high specificity (Lacey \& Singer, 1982) and a complete absence of damaging environmental side effects constitute two of the advantages that this biological agent has over chemical insecticides (Popiel \& Olkowski, 1990). More problematical, however, is the fact that its action is of relatively short duration (only a few days), which means that, to neutralize potential breeding sites, frequent applications have to be made. Certain strains of $B$. sphaericus, such as 1593, 2362, and 2297 (serotype 25), have proved to be even more effective than $B$. thuringiensis $(\mathrm{H}-14)$ against $C$. quinquefasciatus, as well as having the additional advantage of persisting for longer periods under natural conditions and of being recyclable in nature (Lacey \& Singer, 1982; Mulla et al., 1984; Lacey et al., 1988).

It is well-known that the efficacy of these agents depends on environmental factors, such as the water quality of the breeding sites, their richness in nutrients, the climate, the larval density, etc. (Mulla et al., 1985).

For lack of time I have not been able to consult all the available literature describing experiments on the biological control potential of these microorganisms. It is highly probable that other relevant concepts and data exist, such us those arising from experiments carried out in Brazil. Of these, I only have information about those executed by Lacey \& Lacey (1981), involving laboratory assays that tested the effects of $B$. thuringiensis var. israelensis (IPS-78) against $C$. quinquefasciatus and other species of mosquito found in the vicinity of Manaus.

\section{Expanded Polystyrene Balls (EPB)}

In 1978, a new and revolutionary method for controlling populations of $C$.

quinquefasciatus was proposed. It was so simple and cheap that it brought to mind the old story of "Colombo's egg". The method involves pouring polystyrene balls onto the liquid surface inside cesspits and pit latrines, which have always been recognized as providing ideal breeding sites for this species of mosquito. Forming a multilayered floating cover, some $5 \mathrm{~cm}$ thick, the beads prevent, simultaneously, laying of eggs by female, exit of adult mosquitoes, and survival of larvae and pupae. The first two or three layers remain in contact with the water; the higher layers, meanwhile, remain dry and easily return to their original configuration after any disturbance, in such a way that liquids and solids can pass through them without breaking the continuity of the covering layer (Reiter, 1978).

Although EPBs are very light, transporting them over long distances in large volumes would have raised costs to prohibitive levels. For this reason, it was suggested that the balls 
should start out exceedingly small — roughly the same size as sugar granules - and then be expanded by heat treatment (with immersion for 5 minutes in boiling water, for example) somewhere close to their final destination (Reiter, 1985; Curtis \& Minjas, 1985; Maxwell et al., 1990). The ideal average diameter of the expanded balls is 2 mm (Curtis et al., 1986, apud Maxwell et al., 1990).

The beads can be applied manually or mechanically, using a spraying device powered by compressed air (Reiter, 1978).

In an early laboratory experiment, this idea was put into practice with exciting results which suggested that the method could be used in still water breeding sites, as long as protection from wind was ensured, to prevent dispersal of the balls (Reiter, 1978).

Field trials in Tanzania and Kenya (Curtis \& Minjas, 1985; Reiter, 1985; Maxwell et al., 1990), in Zimbabwe (Morgan \& Mara apud Reiter, 1985), and in the United States (apud Curtis \& Minjas, 1985) gave excellent results. In Makunduchi, on the island of Zanzibar (Tanzania), for example, research carried out prior to the trial indicated that each member of the local population was, on average, being bitten by mosquitoes 24,993 times a year.

After the introduction of the polystyrene balls into every infested cesspit, the density of adult mosquitoes fell so dramatically that the average bite rate was reduced to around 439 (Maxwell et al., 1990).

EPBs are biologicaly inert, they do not degrade in water, and in many countries they are easy to obtain. In addition, there is absolutely no risk of mosquitoes ever developing resistance to this method (Reiter, 1978).

\section{DISCUSSION \\ AND RECOMMENDATIONS}

At present, because of the lack of a sewage network in Belém, a very high proportion of the city's houses have cesspits, many of them inadequately sealed. These cesspits provide most of the city's foci (Scaff \& Gueiros, 1967).
There is therefore a clear case for using EPBs in Belém's cesspits and pit latrines, as part of an effectively integrated campaign against filariasis. Such a program might indeed should - be able to count on the participation and support of the local community and of the city authorities. The latter should improve basic sanitation, with a view to eliminating natural breeding sites (through, for example, drainage of ditches, and of other bodies of still water that may be exposed to enrichment with organic matter, such as blocked drains, and poorly installed or damaged gutters, etc.) (Forattini, 1965).

Such an approach would not only help to eradicate this endemic disease from Belém a goal that has long been proposed, in vain (Scaff \& Gueiros, 1969; Fraiha-Neto, 1977) — but it would also, in its own right, bring inestimable social benefits to the population, which still has to contend with the extreme discomfort caused by the high density of $C$. quinquefasciatus population.

In addition, it is clear that this would also be a suitable moment to consider using one of the strains of Bacillus that have already been shown to be effective, and that are already available in the market. A biological insecticide of this kind would provide one more useful weapon and help to ensure that the campaign end in success. It is now up to government officials, to institutional directors, and to political leaders to seize this ripe opportunity.

\section{RESUMO}

FRAIHA-NETO, H. A Filariose

Bancroftiana em Belém, Pará.

Possibilidades Atuais de Erradicação

Mediante a Integração à Campanha de Novos Métodos de Controle da População de Culex quinquefasciatus. Cad. Saúde Públ., Rio de Janeiro, 9 (4): 458-465, out/dez, 1993.

Há mais de quatro décadas Belém é considerada o maior foco de bancroftose da região amazônica e um dos mais importantes do Brasil. Em 1952, praticamente um quinto de sua população apresentava microfilárias no 
sangue, estimando-se em 2.500 os casos de elefantíase. $\mathrm{O}$ fator considerado o maior condicionante de tão extraordinária frequiência era a alta densidade local do principal vetor, Culex quinquefasciatus. Em abril de 1943 calculava-se uma média de 67 fêmeas da espécie infectadas por domicílio. Uma campanha de controle foi deflagrada em 1952, incluindo busca ativa e tratamento dos casos com dietilcarbamazina, além medidas de combate ao vetor. Estas foram abandonadas em 1956, por força da ineficácia ou do alto custo dos inseticidas. Ainda assim, a campanha foi muito bem sucedida, reduzindo a incidência de 19,9 para $0,03 \%$. Hoje, a erradicação poderia ser de pronto lograda, se novos métodos de combate ao vetor fossem adotados, tais como o emprego das bolinhas expandidas de poliestireno nas fossas sépticas e privadas estanques não-inundáveis e o controle biológico com microrganismos entomopatogênicos nos criadouros naturais, sobretudo se acompanhados de um incremento de obras de saneamento.

Palavras-Chave: Filariose; Bancroftose; Culex quinquefasciatus; Controle; Amazônia

\section{REFERENCES}

CAUSEY, O. R.; DEANE, M. P.; COSTA, O. \& DEANE, L. M., 1945. Studies on the incidence and transmission of filaria Wuchereria bancrofti in Belém, Brazil. The A merican Journal of $\mathrm{Hy}$ giene, 41: 143-149.

COSTA, O. R., 1954. Contribuição ao conhecimento da filariose na Amazônia. Revista do Serviço Especial de Saúde Pública, 8: 329-422.

CURTIS, C. F. \& MINJAS, J., 1985. Expanded polystyrene for mosquito control. Parasitology Today, 1: 36.

DEANE, L. M., 1951. Observações sôbre alguns hábitos dos adultos de Culex fatigans, o principal transmissor da filariose em Belém, Pará. Revista do Serviço Especial de Saúde Pública, 4: 423464.

DEANE, L. M. \& DAMASCENO, R. G., 1952. A filariose bancroftiana em Belém, Pará, segundo inquérito realizado em 1951. Revista Brasileira de Malariologia e Doenças Tropicais, 4: 333346.
FORATTINI, O. P., 1965. Entomologia Médica. V. 2, São Paulo: Ed. Universidade de São Paulo.

FRAIHA-NETO, H., 1977. Panorama atual das parasitoses na Amazônia. Revista da Fundação SESP, 22: 07-20.

FRANCO, O. \& SILVA-LIMA, D. M., 1967. Alguns aspectos das atividades contra a filariose bancroftiana no Brasil. Revista Brasileira de Malariologia e Doenças Tropicais, 19: 73-89.

GOELDI, E. A., 1905. Os Mosquitos no Pará. Belém: Wiegandt. [Memórias do Museu Goeldi, 4: 1-154].

LACEY, L. A. \& LACEY, J. M., 1981. The larvicidal activity of Bacillus thuringiensis var. israelensis (H-14) against mosquitoes of the Central Amazon Basin. Mosquito News, 41: 266-270.

LACEY, L. A.; LACEY, C. M.; PEACOCK, B. \& THIERY, I., 1988. Mosquito host range and field activity of Bacillus sphaericus isolate 2297 (serotype 25). Journal of the American Mosquito Control Association, 4: 51-56.

LACEY, L. A. \& SINGER, S., 1982. Larvicidal activity of new isolates of Bacillus sphaericus and Bacillus thuringiensis (H-14) against anopheline and culicine mosquitoes. M osquito News, 42: 537-543.

MAXWELL, C. A.; CURTIS, C. F.; HAJI, H.; KISUMKU, S.; THALIB, A. I. \& YAHYA, S. A., 1990. Control of Bancroftian filariasis by integrating therapy with vector control using polystyrene beads in wet pit latrines. Transactions of the Royal Society of Tropical Medicine and Hygiene, 84: 709-714.

MULLA, M. S.; DARWAZEH, H. A.; DAVIDSON, E. W.; DULMAGE, H. T. \& SINGER, S., 1984. Larvicidal activity and field efficacy of Bacillus sphaericus strains against mosquito larvae and their safety to nontarget organisms. Mosquito News, 44: 336-342.

POPIEL, I. \& OLKOWSKI, W., 1990. Biological control of pests and vectors: Pros and cons. Parasitology Today, 6: 205-206.

RACHOU, R. G., 1956. Transmissores da filariose bancroftiana no Brasil. Revista Brasileira de Malariologia e Doenças Tropicais, 8: 267-279. , 1957. Consideraçõs sôbre o combate à filariose bancroftiana no Brasil. Revista Brasileira de Malariologia e Doenças Tropicais, 9: 527-536.

REITER, P., 1978. Expanded polystyrene balls: An idea for mosquito control. Annals of Tropical Medicine and Parasitology, 72: 595-596. 
1985. A field trial of expanded polystyrene balls for the control of Culex mosquitoes breeding in pit latrines. Journal of the A merican Mosquito Control Association, 1: 519-521.

SCAFF, L. M. \& GUEIROS, Z. M., 1967. Prevalência e contrôle da filariose no Pará: Estado atual. Revista Brasileira de Malariologia e Doenças Tropicais, 19: 245-252.

, 1969. Erradicação da filariose. Revista Brasileira de Malariologia e Doenças Tropicais, 21: 603-613.

SUCAM (Superintendência de Campanhas de Saúde Pública), 1989. Workshop Nacional sobre Filariose Bancrofti. Recife, 31 de maio a 2 de junho de 1989. [Documento Final]. (Mimeo.)
WHO (World Health Organization), 1979. Biological control of disease vectors. Bulletin of the World Health Organization, 57: 911-912.

WICKREMESINGHE, R. S. B. \& MENDIS, C. L., 1981. Evaluation of Bacillus thuringiensis var. israelensis and Bacillus sphaericus 1593 on Sri Lankan strains of larval Culex quinquefasciatus. Mosquito News, 41: 558-559. 